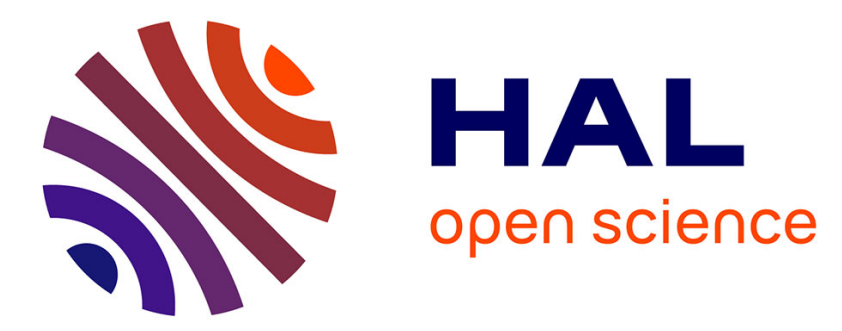

\title{
How Can TRIZ Tools Tremendously Stimulate the Lean Canvas Analysis to Foster Start-Up Business Model and Value Proposition?
}

\author{
Pascal Sire, Eric Prevost, Yves Guillou, Alain Riwan, Pierre Saulais
}

\section{- To cite this version:}

Pascal Sire, Eric Prevost, Yves Guillou, Alain Riwan, Pierre Saulais. How Can TRIZ Tools Tremendously Stimulate the Lean Canvas Analysis to Foster Start-Up Business Model and Value Proposition?. 19th International TRIZ Future Conference (TFC), Oct 2019, Marrakesh, Morocco. pp.93-105, 10.1007/978-3-030-32497-1_9. hal-02905532

\section{HAL Id: hal-02905532 \\ https://hal.inria.fr/hal-02905532}

Submitted on 23 Jul 2020

HAL is a multi-disciplinary open access archive for the deposit and dissemination of scientific research documents, whether they are published or not. The documents may come from teaching and research institutions in France or abroad, or from public or private research centers.
L'archive ouverte pluridisciplinaire HAL, est destinée au dépôt et à la diffusion de documents scientifiques de niveau recherche, publiés ou non, émanant des établissements d'enseignement et de recherche français ou étrangers, des laboratoires publics ou privés. 


\title{
How can TRIZ tools tremendously stimulate the Lean canvas analysis to foster start-up business model and value proposition?
}

\author{
Pascal Sire ${ }^{1}$, Eric Prevost ${ }^{2}$, Yves Guillou ${ }^{3}$, Alain Riwan ${ }^{4}$, Pierre Saulais ${ }^{5}$ \\ ${ }^{1}$ innoppie \& VP TRIZ France, Strasbourg, France - pascal.sire@innoppie.com \\ ${ }^{2}$ Oracle Corp \& President TRIZ France, Paris, France - president@trizfrance.org \\ ${ }^{3}$ Guilbert EXPRESS \& Secretaire TRIZ France, Paris, France - secretaire@trizfrance.org \\ ${ }^{4}$ CEA, LIST, Interactive Robotics Laboratory, Paris, France - alain.riwan@cea.fr \\ ${ }^{5}$ Mines Telecom Institute, Paris, France - pierre.saulais@telecom-em.eu
}

\begin{abstract}
TRIZ is a well-known innovative problem solving method, massively implemented within big industrial groups to boost their efficiency in innovation process. TRIZ is also a creativity technique providing a wide set of methodological formalized concepts applied through numerous tools. Case studies showed how start-ups can benefit from business innovation methodological good practices by enforcing the link between invention, innovation and intellectual property. This paper aims at demonstrating the ability of the formal TRIZ approach to contribute to the feasibility of the next step: helping entrepreneurs and start-ups' stakeholders in accelerating their « serial innovation » capability while keeping the control of the Lean process. To achieve this ambitious and crucial objective, the team will share its best practices of TRIZ expertise aiming at fostering the Lean canvas in-depth analysis thanks to the powerful TRIZ ap propriate tools in order to dramatically reinforce and secure the pioneer spirit.
\end{abstract}

Keywords: Creativity, entrepreneurship, Lean canvas, start-up, TRIZ.

\section{Introduction: which business model for start-up creativity?}

TRIZ is a well-known innovative problem solving method, massively implemented within big industrial groups to boost their efficiency in innovation process, and also a creativity technique providing a wide set of methodological formalized concepts applied through numerous tools (Altshuller, 1988).

Case studies, in an industrial group and a start-up environment, have illustrated the power of the formalism of problem solving by applying the "start-up spirit" for efficient creativity (Sire and al, 2018).

We now want to ever more focus on the innovative start-up context, from both inventive activity and project management points of view.

The first purpose of this paper is therefore, regarding inventive activity point of view, to analyze how the young or recent entrepreneurs can take advantage of the formalism and analogy of the TRIZ state of mind, which is rigorous and oriented toward the search for progress, to foster their innovative activity. (Section 2). 
The second purpose of this paper is, regarding project management point of view, to explore the well-known business models in industry like the Business Model canvas and some derived approaches like Lean Start-up dedicated to a flexible early stage of development, in order to include the Lean canvas in stakeholder strategies (incubators and start-ups, innovative firms) (Section 3).

The third purpose of this paper is to illustrate in a start-up context how to easily fill the Lean canvas thanks to TRIZ methods and tools (Section 4).

The conclusion summarizes the lessons learned, limitations and perspectives of the paper.

\section{How can TRIZ take benefit of the links between invention and the inventive intellectual Corpus to foster innovation?}

\subsection{Links between intellectual property rights and invention}

Our aim here is to show the contribution of information protected by intellectual property rights to the capacity for invention, whether directly (informational support) or indirectly (methodological support).

Direct support of invention patents. Published patents help researchers to explore new fields (knowledge of what exists and of what is protected, understanding of past stages and humility in the face of the future, descriptions of prior art and traceability of technical design choices); patents and publications complement each other.

Publications focus on explaining phenomena while patents are positioned further on in the process, on results, applications and the means used for these applications (Breesé and de Kermadec, 2004). Invention patents have acted as the innovation memory for two centuries (Breesé and de Kermadec, 2004).

The patent also has as a counterpart to meet its obligation to disseminate the scientific and technical content of the invention, allowing "skilled individuals" to be able to reproduce it. The fact that the patent does not protect the idea (or the knowledge), but its materialization allows to insure compatibility between private incentive to invention (by increasing the personal yield from the invention) and technical progress (by disseminating knowledge).

A patent describes the prior art and explains how the proposed solution differs from the existing one, thereby allowing an excellent level of traceability in the choice of technical designs (Breesé and de Kermadec, 2004).

Indirect methodological support for invention patents. Formalizing an innovation "like a patent" (de Kermadec, 2001), that is, by describing certain aspects with documents that follow the editorial rules of patents, can contribute to strengthening this common vision of the work being created (What field is the invention in? What is the problem to be solved? How is the problem currently solved?) in such a way that, by 
appropriating the specific style of invention patents, the team behind the innovative project:

- Clearly defines its objectives;

- Find out the state of the art;

- Can imagine a wide variety of solutions;

- Compare its solutions to others in a synthetic way;

- Strictly formalizes what it wants to do;

- Communicates more effectively;

- Is more aware that it is teamwork that allows "the best solution" (de Kermadec, 2001) to be created.

Formalizing and creating are therefore indivisible (de Kermadec, 2001); "patent style" formalization is particularly suited to the inventive approach. Pierre Breesé and Yann de Kermadec confirm that reinvention is highly expensive and a record of the company's creations should be kept.

Using an innovation-base (that is, a knowledge base dedicated to innovation products and processes) allows ideas to be saved so that they can be used at the right time, as well as avoiding reinvention, and identifying problems, solutions and the people to contact. It contains innovation files, innovation memos, patents, files of inventions that have not been retained, and so on (Breesé and de Kermadec, 2004).

In this way, the link between industrial property and innovation is shown in the fact that databases of invention patents are unrivaled and often exclusive sources of technological and scientific information, presented according to powerful formalism, methodologically speaking.

\subsection{Reciprocal links between inventive activity and the inventive intellectual corpus}

Our ICAROS $®$ method uses analysis of the inventive intellectual corpus to stimulate inventive activity (Saulais and Ermine, 2016a); the inventive intellectual corpus of an organization contains basic elements that allows for the representation of a certain number of inventive trajectories undertaken by the organization's knowledge actors by linking the inventive intellectual traces that have been left (patents, theses, reports of advanced studies). A reasoned analysis of the traces thus restores the intellectual path drawn by the trajectories of these traces, giving a strategic evolution of the inventive intellectual corpus that has been inventoried over several years.

The assessment obtained by this process of collecting and explaining inventive knowledge that has led to a new design, is then put into perspective with the potential knowledge in each field (representing an absolute reference) to form a cognitive stimulus applied to experts representing each area of knowledge, who individually have potential elements for the identification and the explanation of which they have to be guided in order to help them develop a forward-looking vision of their field (Saulais and Ermine, 2016a). 
The reciprocity is expressed through the analysis, extraction and implementation of the inventive knowledge, with this new inventive knowledge going on to enrich the inventive intellectual corpus (Saulais, 2016b), (Saulais, 2016c), as illustrated by Figure 1 , which focuses on the dossier on inventive activity called Invention \& Innovation File.

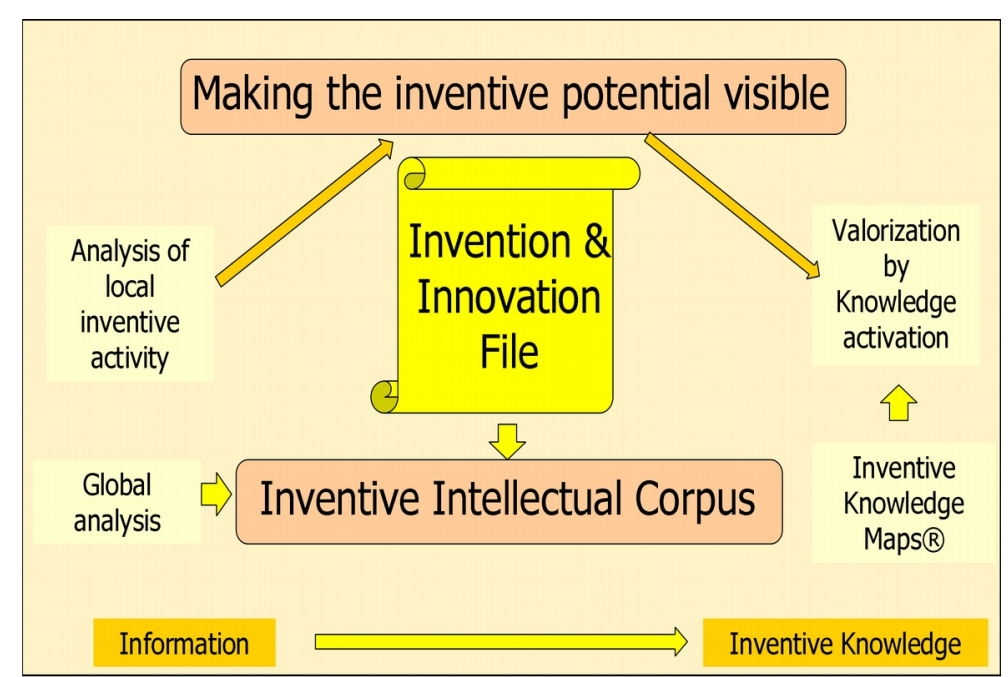

Fig. 1. Analysis of inventive activity - Source: author

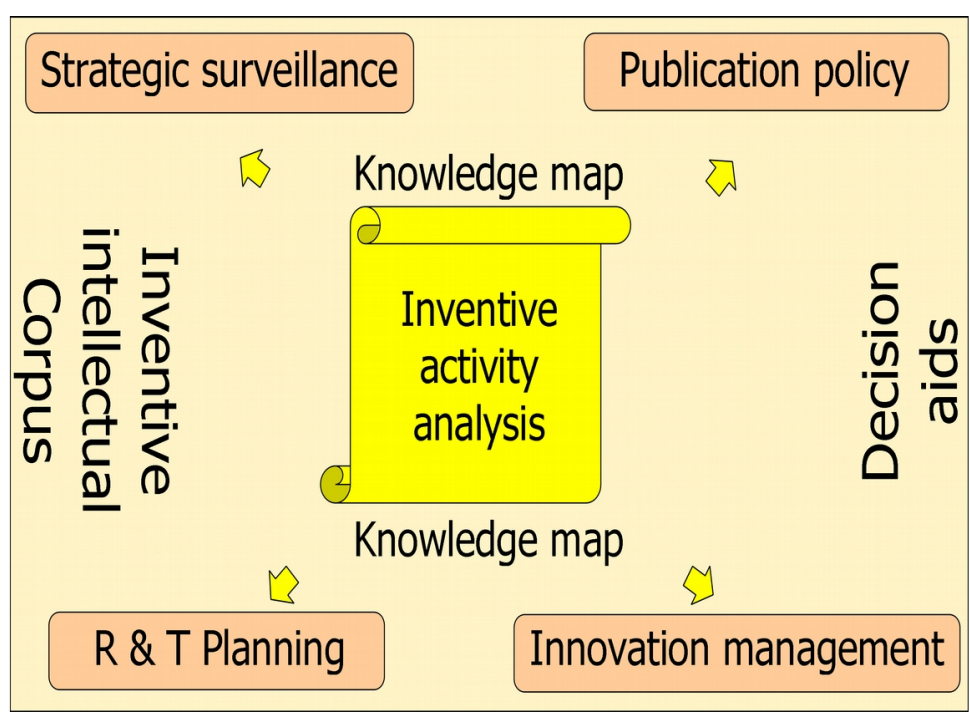

Fig. 2 Applications for showing analysis of inventive activity in knowledge maps Source: author 
Figure 2 illustrates the applications of analysis of overall inventive activity (contained within the inventive intellectual corpus) to support decision-making in different fields.

\subsection{Synthesis}

We defined invention, innovation and intellectual property rights as objects of knowledge.

We thus presented each of the three objects of knowledge, primarily the act of innovating and its outcome, followed by the ability to invent, and lastly the inventive intellectual corpus and intangible capital. By considering each object of knowledge to represent its own field of knowledge, we have examined the links between the three fields both in a static sense and in a dynamic sense of one thriving on the other, in a pure start-up spirit.

Having highlighted the benefits of applying a structured and reasoned method to technical fields of innovation, we now want to explore its application to other fields of innovation, mainly in the management domain. This is the ambition of sections $3 \& 4$.

\section{From Business model to Lean Canvas}

How can an organization innovate? "To achieve organizational innovation, every facet of a business needs to move together in the same direction. That can be difficult without a clear visual of what your business model is and how your activities should be aligned. You need to identify what your company wants -and is prepared- to do before innovation can turn from a buzzword into an action" (Hemmer, 2016).

\subsection{Business model canvas}

The Business Model Canvas is a methodology on the rise that helps companies visualize and position their business models for growth and innovation. Strategyzer defines it as "a strategic management and entrepreneurial tool. It allows you to describe, design, challenge, invent, and pivot your business model." (Strategyzer, 2019).

It breaks your business model down into easily-understood segments: Key Partners, Key Activities, Key Resources, Value Propositions, Customer Relationships, Channels, Customer Segments, Cost Structure, and Revenue Streams.

"It also reveals clear paths on which to build your organizational innovation strategy. It helps you communicate your goals to your team. It helps communicate to clients why they should do business with you. It helps pull into focus what your business does and how it will continue to do it -successfully- into the future." (Hemmer, 2016).

The Business Model Canvas has been a great invention for everyone from startups to large companies. Unlike an org chart, which describes how a company manages the delivery of known products to known customers, it illustrates the search for the un- 
knowns. The 9 boxes of the canvas let you visualize all the components needed to turn customer needs/problems into a profitable company.

\subsection{Lean start-up}

The Lean Startup provides a scientific approach to creating and managing startups and get a desired product to customers' hands faster. "The Lean Startup method teaches you how to drive a startup-how to steer, when to turn, and when to persevereand grow a business with maximum acceleration. It is a principled approach to new product development" (Ries, 2012).

Wikipedia defines Lean startup as "a methodology for developing businesses and products, which aims to shorten product development cycles and rapidly discover if a proposed business model is viable; this is achieved by adopting a combination of business-hypothesis-driven experimentation, iterative product releases, and validated learning".

Central to the lean startup methodology is the assumption that when startup companies invest their time into iteratively building products or services to meet the needs of early customers, the company can reduce market risks and sidestep the need for large amounts of initial project funding and expensive product launches and failures (Wikipedia, 2019).

The Lean Startup is the way most innovators build startups and innovate inside of existing companies. As a formal method, the Lean Startup consists of three parts:

- The Business Model Canvas - to frame hypotheses

- Customer Development - to test those hypotheses in front of customers

- Agile Engineering - to build Minimum Viable Products to maximize learning.

\subsection{Lean Canvas}

The Business Model Canvas was proposed by Alexander Osterwalder based on his earlier book: Business Model Ontology. It outlines several prescriptions which form the building blocks for the activities. It enables both new and existing businesses to focus on operational as well as strategic management and marketing plans.

The Lean Canvas, on the other hand, has been proposed by Ash Maurya as a development of the Business Model Generation. It outlines a more problem-focused approach and it majorly targets entrepreneurs and startup businesses (Canvanizer, 2019).

Ash Maurya's main objective with Lean Canvas was making it as actionable as possible while staying entrepreneur-focused. The metaphor he had in mind was that of a grounds-up tactical plan or blueprint that guided the entrepreneur as they navigated their way from ideation to building a successful startup.

He had already been working with Lean Startup principles which had a big influence on the design. His approach to making the canvas actionable was capturing what was most uncertain, or more accurately, what was most risky (MAURYA, 2015). 
Unlike Business Model Canvas, the Lean Canvas focuses on: Problem understanding (avoiding working on the wrong problem), Solution (purposefully within a small box to avoid spending time and resources), Key metrics (just a very few that matter), and Unfair Advantage (another name for competitive advantage or barriers to entry).

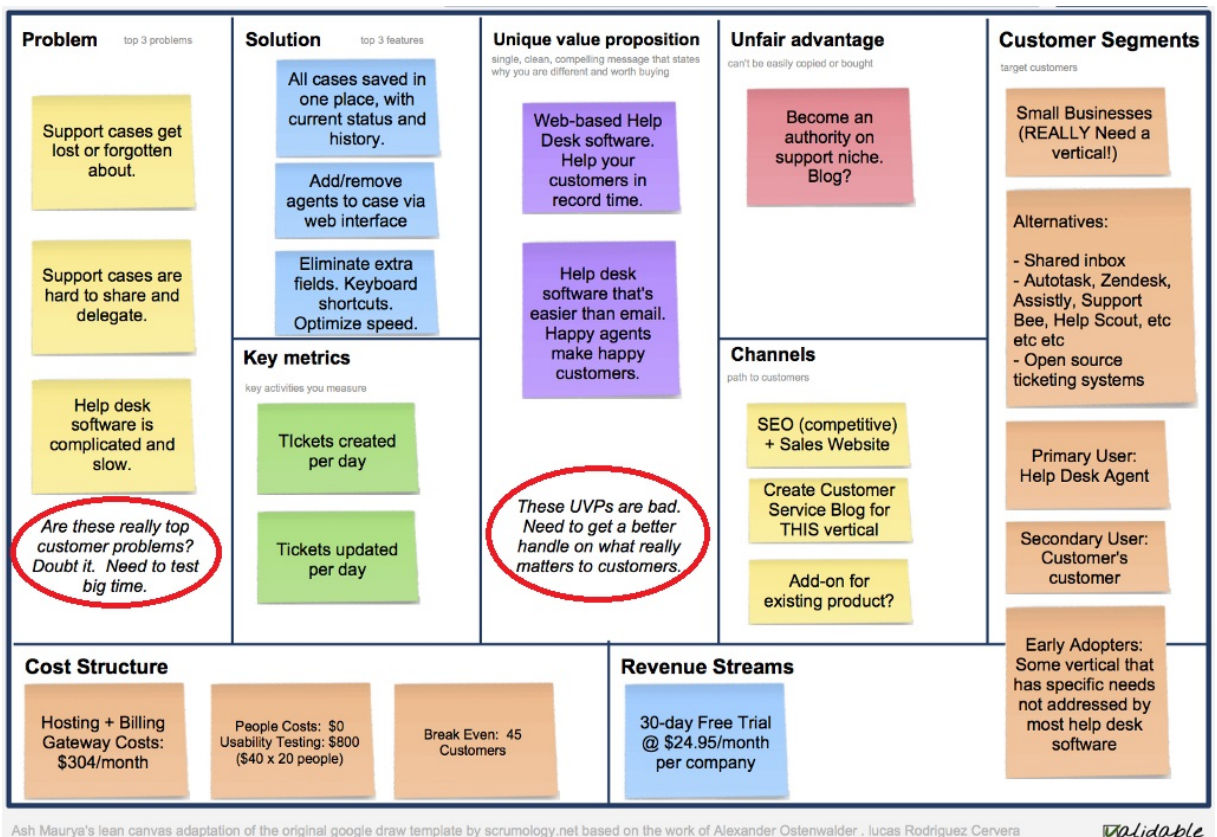

Fig. 3 Lean Canvas (Keylime example) - source Steve Mullen

"Going through the nine steps on Lean Canvas helped me to understand what information really matters in creating a start-up. I feel that identifying the problem and the solution are the most important steps in the Lean Canvas process. They are the sole purpose of your product and you must ensure that a problem does exist in order for your product to be successful." (Nancyaviles, 2012).

The Lean Canvas is a one-page strategic tool, in the Lean Startup spirit, that defines a startup or product and helps document and validate an inventive business plan.

Table 1. Lean Canvas details and suggested order - source: Ash Maurya

\begin{tabular}{|l|l|l|l|l|}
\hline \multicolumn{2}{|c|}{ PRODUCT } & \multicolumn{2}{c|}{ MARKT } \\
\hline $\begin{array}{l}\text { 2-Problem } \\
\text { Top 3 problems }\end{array}$ & $\begin{array}{l}\text { 4-Solution } \\
\text { Top 3 features }\end{array}$ & $\begin{array}{l}\text { 3-Unique } \\
\text { Value Prop }\end{array}$ & $\begin{array}{l}\text { 9-Unfair } \\
\text { Advantage }\end{array}$ & $\begin{array}{l}\text { 1-Customer } \\
\text { Segments }\end{array}$ \\
\hline $\begin{array}{l}\text { 2b-Existing } \\
\text { Alternatives }\end{array}$ & $\begin{array}{l}\text { 8-Key Metrics } \\
\text { Key activities }\end{array}$ & $\begin{array}{l}\text { 3b-High level } \\
\text { Concept }\end{array}$ & $\begin{array}{l}\text { 5-Channels to } \\
\text { Customers }\end{array}$ & $\begin{array}{l}\text { 1b-Early } \\
\text { Adopters }\end{array}$ \\
\hline 7-Cost structure (fixed, variable) & & 6-Revenue streams (sources) \\
\hline
\end{tabular}


How to help entrepreneurs and start-ups'stakeholders in accelerating their « serial innovation » capability while keeping the control of the Lean process?

If identifying the problem and the solution are the most important steps, what about the ability of the formal TRIZ approach to contribute to the feasibility of this ambitious and crucial objective?

\section{$4 \quad$ TRIZ helps filling the Lean Canvas}

According to authors (MAIA \& al, 2012), "Lean and TRIZ share a main idea: design and delivery products to the clients that they really want. In order to achieve this, both use principles and tools having in mind reducing the waste or minimizing the usage of new resources and both uses a procedure of continuous improvement."

\subsection{TRIZ and Systematic Business Model Innovation}

As early as 2010, Valeri Souchkov presented at the TRIZ Future Conference in Bergamo an approach to Business Model Innovation based on a combination of key TRIZ principles and tools and a new approach to business modeling which introduces building blocks to describe and represent business models.

Developing a competitive business model is essential for any business organization since the model defines the company strategy and future on the market. However in the modern times of accelerated innovation business models might not remain static: ever changing business environment requires continuous innovation of both technology and the ways of doing business. The traditional way of innovation which relies on random methods of idea generation does not seem fitting the picture any longer. Instead, new systematic and structured methods supporting continuous process of new business ideas generation are emerging.

Application of key TRIZ tools and concepts such as Ideality, Contradictions, Resources and Trends of Business Systems Evolution within the context of business models was discussed. Such a combination helps to:

- represent business models in terms of building blocks and describe business models clearly and in a structured way without overloading it with numerous details;

- systematically assess and analyse business models with TRIZ analytical tools; locate and define problems, contradictions and areas with high evolution potential;

- apply the TRIZ tools for business and management problem solving and ideas generation to innovatively modify existing business models or to design new, innovative business models for a specific market or industry (Souchkov, 2010).

As an example was shown a contradiction mapping revealed with $\mathrm{RCA}+$ to relevant building blocks of a business model. 


\subsection{TRIZ Method Aligns with Organizational Practices for Innovation}

At TFC 2012, Helena Navas studied the TRIZ-Lean Environment: "The Lean approach is to find the best compromise between contradictions, whereas the TRIZ approach is to eliminate contradictions avoiding the compromise or trade off. TRIZ can be seen as a Lean tool. There are many Lean techniques and concepts where TRIZ might be applied." (NAVAS, 2012).

As an example, in "8 Discipline" (8D), one of the Lean problem solving tools, TRIZ may help in the 8D problem solving process: in D2 step (Describing the Problem) to identify contradictions and to define and to valuate problems, in D5 step (Choosing Corrective Actions) with many and varied generic solutions available with several TRIZ tools, etc. The TRIZ tools would help to 8D become more systematic, effective and successful method of problem solving. Also, TRIZ might help with waste reduction, the TRIZ concept of ideal system presents similarities with the Lean search for systems without cost or harm (without waste), etc.

According to Paul Hobcraft, the use of the Lean management as above have shown "a consistent change over the years to move towards a more inventive engineering and discovery mindset within our innovation approaches." (Hobcraft, 2017). It started in manufacturing, continued in logistics and supply chain and evolved in labs and thinking to keep advancing processes, thinking and growth inside our organizations. Far more outside is now looked to connect into the customer's specific needs.

"The Lean Startup movement has been a significant part of the fusing of internal learning becoming more agile and understanding of what customers really want. It takes agility as central to this evolving through learning and constant discovery.", he says (Hobcraft, 2017). Minimum viable propositions are now built into problem-solving thinking, extending prototyping into discovery process, and learning to pivot on the go.

Designing the Business Model through the Canvas has appealed to those that believe they are visionaries, game changers, and challengers striving to defy outmoded business models and design tomorrow's enterprises. This has spawned a variety of visual tools, different canvases as strategic and operational ideas and tools, and makes them easy to implement in any organization.

"TRIZ is a problem solving method based on logic and data, not intuition, which accelerates the project team's ability to solve these problems creatively. TRIZ also provides repeatability, predictability, and reliability due to its structure and algorithmic approach. New TRIZ tools are being developed, with active groups working on this. These are more advanced tools applied to help in: functional oriented search (FOS), main parameters of value (MPV) analysis, Voice of the Product (VOP), etc." (Hobcraft, 2017). 


\subsection{Lean Canvas with TRIZ tools}

At TFC 2014, Teemu Toivonen proposed forming a hybrid "continuous innovation" model by combining Toyota Kata with TRIZ techniques. He said: "It is only one possible solution and there is a lot of room for different approached due to the large amount and flexibility of TRIZ techniques available."

A guiding principle for the author has been to try to evaluate not only how well an individual technique works, but how well it fits together with the other techniques. The idea has not been to map all possible TRIZ techniques to Toyota Kata, but rather to give examples of how that mapping can be done (Toivonen, 2014).

With such a spirit, the authors would like to share an easy to use, quick and efficient way to fill the Lean Canvas boxes using some of the well-known Classical TRIZ tools. This was done several times, within incubators for a few start-ups at early stage, and within a worldwide-class SMB wanting to take advantage of the "start-up spirit".

Table 2. Lean Canvas boxes and an example of TRIZ toolkit - source: authors

\section{Lean Canvas boxes}

1. Problem

2. Customer Segments

3. Unique Value Proposition

4. Solution

5. Channels

6. Revenue Streams

7. Cost Structure

8. Key Metrics

9. Unfair Advantage
Example of TRIZ toolkit

- Thinking in Time and Space

- Trends of Technical Evolution

- Contradictions

- Resources

- Ideality

- Functional Analysis

- 40 Inventive Principles

- 76 Standard Solutions

- Size-Time-Cost, etc.

Among the many possibilities of cross-linkage, the Figure 4 proposes one case, without content in the Lean Canvas boxes due to IP reasons (Prevost and al, 2014).

For example, to be discussed during the TFC presentation, some suggestions:

- first step in to get a textual explanation of the customer issues using the TRIZ contradiction schema to summarize the owner's vision of the problem to solve;

- filling the box 2 "Customer segments" using the TRIZ Time \& Operational zones;

- filling the box 3 "Unique Value Proposition" thanks to the TRIZ ideality;

- filling the box 4 "Solution" is quite easy with TRIZ as problem-solver;

- etc. 


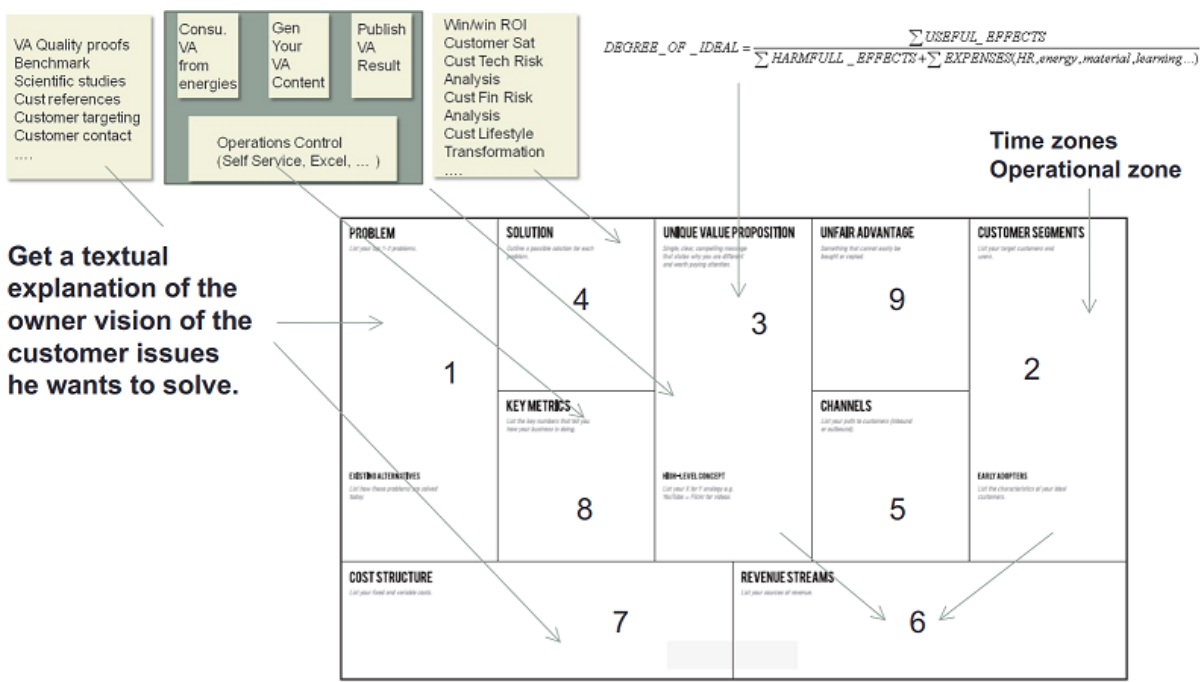

Fig. 4 Lean Canvas boxes filling with TRIZ tools - source: authors

Last but not least, Figure 5 show resonance from startups (Prevost and al, 2014). For example: the start-ups' owners discovered the power of the Evolution Laws to imagine the next innovation after their first one, they were confortable with the Time zone and Operational zone to focus on when and where do the customer pains occur, the multi-screen was appreciated to understand the different layers of systems and times around their innovative product or service, also ideality and S-Curve, etc.

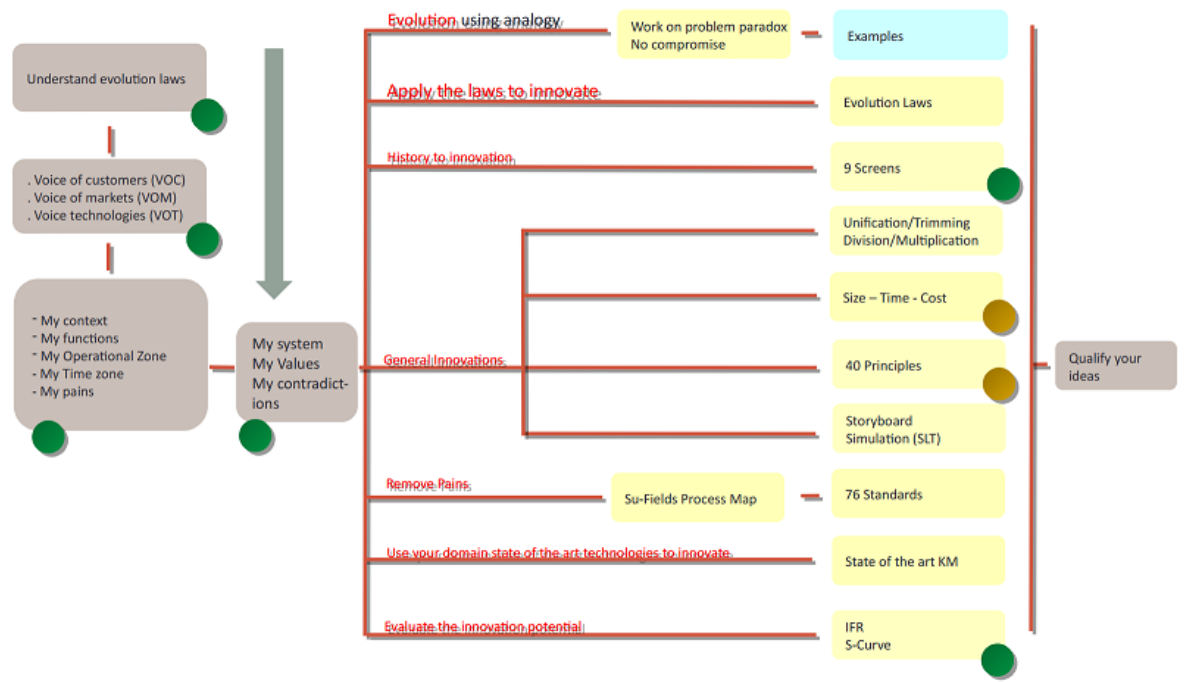

Fig. 5 LeanCanvas and TRIZ feedback from startups - source: authors 


\section{Conclusion}

In this paper aims, we demonstrated the ability of the formal TRIZ approach to contribute to the feasibility of the next step: helping entrepreneurs and start-ups'stakeholders in accelerating their " serial innovation » capability while keeping the control of the Lean process.

To achieve this ambitious and crucial objective, the authors shared their best practices of TRIZ expertise aiming at fostering the Lean canvas in-depth analysis thanks to the powerful TRIZ appropriate tools in order to dramatically reinforce and secure the pioneer spirit.

Next step would be to carry over other real-life case studies. Does the TRIZ community have such examples or experiences to share and learn from?

\section{References}

1. Altshuller G (1988) Creativity as An Exact Science: The Theory of the Solution of Inventive Problems. New York, Gordon \& Breach

2. SIRE Pascal, PREVOST Eric, GUILLOU Yves, RIWAN Alain \& SAULAIS Pierre "TRIZ and Intellectual Property to strengthen the start-up spirit" TRIZ Future Conference, Strasbourg, France, 2018.

3. BREESE, Pierre, et Yann de KERMADEC. La Propriété intellectuelle au service de l'innovation. Paris: Nathan, 2004.

4. de KERMADEC, Yann. Innover grâce au brevet. Paris: Dunod, 2001.

5. LAPERCHE, Blandine. «Brevets et normes techniques : de l'incitation à l'invention au contrôle de l'innovation." Dans Propriété industrielle et Innovation, de Blandine LAPERCHE, 81-98. Paris: L'Harmattan, 2001.

6. SAULAIS, Pierre. «Application de la gestion des connaissances à la créativité des experts et à la planification de la R\&T en milieu industriel de haute technologie." Thèse de doctorat, Télécom Ecole de Management, 2013.

7. SAULAIS, Pierre. «Mise en visibilité du potentiel inventif et représentation du patrimoine intellectuel inventif." Veille Mag, ${ }^{\circ} 155$ Spécial Gestion des Connaissances (2016b).

8. SAULAIS, Pierre «Analyse, cartographie et mise en action de la connaissance inventive." GeCSO. Paris, 2016c.

9. SAULAIS, Pierre, et Jean-Louis ERMINE. «Emergence d'innovation technologique incrémentale par aplication, à des experts, de l'analyse du patrimoine intelectuel inventif." Édité par De Boeck. Innovations 49, $\mathrm{n}^{\circ} 1$ (2016a): 103-140.

10. HEMMER, Mark, 2016. https://blog.onefire.com/why-a-business-model-canvas-is-important-to-organizational-innovation

11. STRATEGYZER "Canvas", 2019. Seen on https://www.strategyzer.com/canvas

12. WIKIPEDIA "Lean Startup", 2019. Seen on https://en.wikipedia.org/wiki/Lean_startup

13. RIES Eric (2012) The Lean Startup, Pearson, 2012. Retrieved on http://theleanstartup.com/principles

14. CANVANIZER, retrieved on 2019. https://canvanizer.com/how-to-use/business-modelcanvas-vs-lean-canvas

15. MAURYA Ash, 2015. https://www.linkedin.com/pulse/why-lean-canvas-vs-businessmodel-ash-maurya 
16. NANCYAVILES, 2012. https://nancyaviles.wordpress.com/2012/10/27/lean-canvaslessons-learned

17. MAIA L C, ALVES A C, LEAO C P "How could the TRIZ tool help continuous improvement efforts of the companies?" TFC 2012.

18. NAVAS Helena V. G., MACHADO Virgílio A. Cruz, "The Lifeline of Technical Systems in a TRIZ-LEAN Environment”, Procedia Engineering 131 (2015) 232 - 236, TFC 2012

19. SOUCHKOV, Valeri "TRIZ and Systematic Business Model Innovation", 2010, Published in the Proceedings of the "TRIZ Future Conference 2010", Bergamo, Italy, November 3-5, 2010, Bergamo University Press, pp 189-197. ISBN: 978-88-9633359-4. Retrieved on https://triz-journal.com/triz-and-systematic-business-model-innovation

20. TOIVONEN Teemu, "Continuous innovation - combining Toyota Kata and TRIZ for sustained innovation", Procedia Engineering 131 (2015) 963 - 974, TFC 2014

21. PREVOST E, BRUNO G, GUILLOU Y, SIRE P \& CONRARDY C (2014) "What roles can TRIZ play in Start-up incubators?" Global TRIZ Conference 2014, Seoul, Korea 